Prace Literackie LVII

Wrocław 2017

DOI: $10.19195 / 0079-4767.57 .10$

\title{
Medzi liminalitou a slobodou aj ako prejav diskurzivity (pop)(sub)kultúry v súčasnom slovenskom alternatívnom divadle*
}

V súčasnosti, v epoche náhlych civilizačných metamorfóz, návratu dominancie štruktúr kapitalistického neokolonializmu a arogancie stanovujúcich podložie vlády politikov vo vzt’ahu $\mathrm{k}$ individualitám tvoriacich artefakty, od začiatku nastavených ako svet hodnôt nepodliehajúci ekonomickým princípom a trhovému hospodárstvu, sa radikálne zmenil význam pojmu slobody cenený v každej kultúre a stanovujúci základný pilier filozofie človeka.

Tento pojem, kde relevantnú perspektívu tvorila prepojenot' na prirodzený zákon, akým bola sebarealizácia osobnosti v súznení s jej vlastnou intuíciou a pocitom zmysluplnosti bližšie určených aktivít, perspektíva vyrastajúca zo žriedel v mimetickom prenesení čŕt upevňujúcich vzorce, ktoré udržiavajú civilizáciu $\mathrm{v}$ harmonickom vnútornom pute, bol nahradený iluzórnou konfrontáciou hodnoty kreovanej a reprezentovanej v umení s abstraktnou dominantnou silou, ktorú dnes nepredstavuje nič iné než sú peniaze.

Elita sponzorov a mecénov kultúry zaobchádza — nemajúc o tom poňatia $\mathrm{s}$ princípom charakterizujúcim feudalizmus $\mathrm{v}$ Heglovej historiozofii, ked' onen Pán hovorí svojmu „sluhovi““ „,budeš jest' chlieb, ale z mojej ruky“. Ten, aby prežil a mohol vykonávat' to, čo je mu blízke, a tak naplnit' sebarelizačné potreby, súhlasí, aby jeho sloboda bola pozbavená individualizmu a jej čiastková realizácia, ktorú Pán, samozrejme, dovol'uje, prijíma znaky svojvôle nakoniec stotožnenej so slobodou.

Sloboda teda preberá na seba postoj akceptovaného výstrelku alebo povolenej ,,inakosti“. Dialo sa tak prevažne vtedy, ked’ sa umelcovi umožňovala ohraničená sloboda a „vymazávalo“ sa jeho šialenstvo, ako sa vravelo, iba preto, že je ,umeleckou dušou“. Tento frazeologizmus sa objavuje rovnako aj v súčasnom

* Táto štúdia je jedným z výstupov grantového projektu VEGA 1/0570/15. 
jazyku vyjadrujúcom mentalitu benevolentných vládcov (to znamená sponzorov a mecénov) odpúšt'ajúcich excesy umelcom.

Možnost' manifestácie svojej „inakosti“, individualizmu a suverenity je síce prijímaná s pochopením a zapojená do priestoru excesu umelca, no je viac než zrejmé, že bol narušený poriadok odvolávania sa na axiomu a na jeho miesto prenikol poriadok ,zodpovednosti“ $\mathrm{v}$ rámci systému.

Sloboda bola zamenená - ako o tom podnetne uvažuje Włodzimierz Szturc — za ,simulakrum“, čo je zdanlivý a zradný obraz prezentovanej skutočnosti ako rozvíjajúcej sa, podrobenej zákonom zdokonalenia a obohacovania. ${ }^{1}$ Je to svet, ako píše Baudrillard ${ }^{2}$, konštruovaný l'ud’mi zažívajúcich „zázrak konzumnosti““ tvoriaci súbor hotových produktov poskytujúcich štastie, magicky predstavujúci ilúziu ako skutočnost' v reklamách, rozličných podobách marketingových zliav, médiách rôzneho typu (televízia, rozhlas) najčastejšie adresovaných masovému príjemcovi.

Ked’že umenie a jej tvorcovia sa zodpovedne odvolávajú na kultúru či popkultúru, vd'aka ktorej sa povedzme literatúra a v jej rámci dráma alebo divadlo stali predmetom ich fascinácie, mali by stát na stráži duchovnej kontinuity kultúry, odovzdávat' Aristotelovu entelechiu, čiže vytvárat' elementy ret'aze spájajúcej žriedla a ciele umeleckých činností — v našom prípade európskej kultúry. Slúžiac základnému princípu mimesis vo vzt’ahu ku skutočnosti i k mýtu — autori alebo aj umelci v najširšom zmysle slova predstavujú modelové vzt’ahy panujúce $\mathrm{v}$ tomto svete, nie zriedkavo sa z nich vysmievajúc, rúhajúc sa im, zvádzajúc ich na reálne smetisko histórie.

V tejto súvislosti sa zdá byt' podnetným kritický pohl'ad Friedricha von Hayeka, „pápeža liberalizmu“ — ako ho označil Roman Berger — ktorý upozorňuje, že demokracia je ideál, ku ktorému sa konkrétne demokracie môžu približovat' iba za predpokladu, že budú nekompromisne presadzovat' do praxe nielen právne pravidlá [...], ale najmä pravidlá zo sféry „spontánneho poriadku“ — princípy kultúry, ktoré vyplývajú zo spoločenskej kultúrnej „tradície“.3

Univerzalizmus Hayekovej myšlienky ani na moment nepripúšs’a, poslúžiac si úvahami Romana Bergera, „že by napríklad mohla fungovat' akási ekonomika sama o sebe, vytrhnutá z kontextov komplexnej reality, v ktorej fundamentálnu úlohu hrajú práve spontánne procesy Prírody vyúst’ujúce do štruktúry kultúry““. Hayekovu názorovú platformu Berger rozvíja d’alej:

${ }^{1}$ Pozri Postmodernizm. Antologia przekładów, red. R. Nycz, Kraków 1998, s. 27. alebo W. Szturc, Twórca nowego teatru a symulakrum wolności, [v:] Havlovské dialogy - paradox svobody [Dialogi Havlowskie - paradoks wolności], Cieszyn 2014, s. 20.

2 Podla J. Baudrillard, Społeczeństwo konsumpcyjne. Jego mity i struktury, Warszawa 2006, s. 116.

3 R. Berger, Cesta s hudbou. (Od Palacha po Obamu - a po Štefánika). Výber textov z rokov 1969-2009, Bratislava 2012, s. 142.

${ }^{4}$ Ibidem. Pozri tiež viaceré odborné texty a referáty Tatiany Pirníkovej, v ktorých analyzuje myšlienky Romana Bergera (napr. známky duchovnosti, siahanie za transcendenciou, prítomnost' 
Znepokojuje, že túto koncepciu sme u nás neprijali. Že hned’ v začiatkoch „radikálnej ekonomickej reformy“" sa povedalo, že na kultúru teraz nie je čas. [...] A nielen u nás žijeme v situácii hlbokej krízy kultúry vyplývajúcej z antropocentrizmu, z vládnucej paradigmy klasickej vedy a z nej odvodenej likvidácie horizontu Sacrum: zo zosmiešnenia všetkého, čo súvisí s Transcendenciou. [...] Ked’že kultúra sa adaptovala na „civilizačné procesy“, stala sa z nej „konzumná kultúra“, zabudlo sa, že „konzum“a „kultúra“ sa navzájom vylučujú, že ide o — zd’aleka nie ojedinelý - príklad contradictio in adjecto, a tým o nezmysel. ${ }^{5}$

Nemecký filozof Martin Heidegger sa vyslovil, že evolúcia myslenia dospela na úroveň dialektiky, teda na úroveň reflexie, čo znamená, že sme povinní konfrontovat' svoje automatické myslenie s princípmi, s Pravdou, s pravidlami spontánneho poriadku kultúry. Hovorí, že nivelizácia vedie k chaosu, k entropii. ${ }^{6}$

Uvol'nenie, ktoré po roku 1989 nastalo, sa prejavilo aj mnohými zmenami v divadle i dramatickej tvorbe. Objavilo sa pomerne mnoho nových autorov a hier. Pôvodná dráma sa však na javiská vel'kých divadiel dostáva len vel'mi pozvol’na. Jedným z dôvodov je aj pretrvávajúca nedôvera divákov a divadiel voči súčasnej dráme. Divadlá sa od začiatku devät’desiatych rokov prakticky až dodnes stretávajú s problémami súvisiacimi so zmenou organizačnej štruktúry, financovania a audience buildingom. Proces hl’adania novej tváre slovenských divadiel sa odrážal — ako to správne označil Ján Šimko — najmä

v zmätočnej dramaturgii, ktorá vedl’a seba ukladala často marginálne tituly staršej svetovej i domácej drámy vedl’a ešte marginálnejších titulov súčasnej svetovej drámy. Väčšina slovenských divadiel, žial', rezignovala na pozitívne inscenačné tradície, ktoré vybudovali predchádzajúce generácie. ${ }^{7}$

Možno konštatovat', že sa dramatická a divadelná tvorba zásadným spôsobom diverzifikovala. V čase, ked' od divadiel neprichádzala iniciatíva inscenovat' pôvodné hry súčasníkov, podporovali tieto aktivity iné subjekty — súdobé Národné divadelné centrum (NDC), jeho nástupca Divadelný ústav Bratislava a odborné teatrologické časopisy. NDC usporiadalo v rokoch 1991-1997 Festival inscenácií slovenských hier. ${ }^{8}$ Časopis Medzičas vyhlasoval začiatkom devät'desiatych rokov sút'až pre dramatikov, ktorá bola napojená na iné európske sút’aže, ale v polovici decénia zanikla. Dôležitým stimulom pre dramatikov a divadelných tvorcov je česká Cena Alfréda Radoka ${ }^{9}$, ktorej sa môžu zúčastnit’ — a úspešne sa i zúčastňu-

paradoxu v hudbe; proces, $\mathrm{v}$ ktorom prináša skladba svedectvo o smrti; meditatívnost' vo vzt'ahu k času - ako trvanie a ako proces a i.). Napr. T. Pirníková, Meditácia ako výsledok dozrievania, svedectvo o poznaní, [v:] Súčasné umenie v medzidisciplinárnej komunikácii. Studia Aesthetica XI, ed. J. Sošoková, Prešov 2009, s. 331-340.

5 Ibidem, s. 142-143.

6 Podl'a R. Berger, op. cit., s. 146.

7 J. Šimko, Periféria v centre Európy, [v:] Katalóg slovenských súčasných dramatikov, ed. J. Beňová, J. Šimko, Bratislava 2006, s. 14.

8 Prvý ročník sa konal v Bratislave (1994), d’alšie tri v Prešove (1995, 1997).

9 Ide o anonymnú sút’ǎ o cenu za najlepšiu pôvodnú divadelnú hru. Vyhlasuje ju Nadačný fond Cien Alfréda Radoka v spolupráci s divadelnou a literárnou agentúrou AURA-PONT. Tejto sút'aže sa môže zúčastnit’ český alebo slovenský autor s pôvodnou hrou, ktorá ešte nebola uvedená 
jú - aj slovenskí dramatici. V roku 2000 vyhlásil bratislavský Divadelný ústav sút'až DRÁMA ${ }^{10}$ roka, do ktorej je každoročne prihlásených okolo tridsat' textov.

Najsilnejšou žijúcou tradíciou, formujúcou súčasnú slovenskú drámu a divadlo, ostáva nad’alej tradícia alternatívnych štúdiových divadiel, ktorá zanecháva na hrách súčasných autorov najvýraznejšie stopy. V (polo)profesionálnych i amatérskych divadlách alternatívneho alebo štúdiového typu (napr. niekdajšie Divadlo Kopánka Trnava, jeho nástupca Divadlo DISK Trnava ${ }^{11}$, Divadlo GUnaGU Bratislava, Divadlo Stoka Bratislava, Divadlo SkRAT Bratislava, Teatro Tatro Nitra, Divadlo Pôtoň Bátovce, Bábkové divadlo na Rázcestí, Divadlo Neon Košice, Prešovské národné divadlo a i.) ${ }^{12}$ sa v prítomnosti hry súčasných autorov aj inscenujú. Ak sa objaví nejaká „vel'ká hra“, teda hra, ktorá svojou témou a spracovaním obsiahne priestor vel'kého javiska a unesie kritériá pravidelného uvádzania $v$ repertoári, je to skôr vec št’astnej náhody.

Akokol'vek paradoxne môžu vyzniet' a neraz aj vyznievajú dopady fenoménu slobody premietajúce sa do života súčasníka, v kultúrnej (a v užšom zmysle rovnako popkultúrnej) oblasti sú jej prínosy viac než badatel'né. Môžeme to plasticky demonštrovat' na situácii tvorcu súčasnej divadelnej kultúry. Ak by sme chceli byt' konkrétni a transfokovali by sme náš pohl'ad na prítomnú situáciu umelca, povedzme, aj v oblasti alternatívneho divadla, mali by sme zrejme zdôraznit', že celé množstvo genologických špecifík tvoriacich poetologickú bázu súčasných divadelných produkcí rozmanitého typu nebolo v predošlom politickom systéme myslitel’ných, ba mnohé z nich radový tvorca socialistickej kultúry ani nepoznal. Kým v období normalizačných sedemdesiatych a následne osemdesiatych rokov minulého storočia prevládali v kultúre a umení (a nielen divadelnom) prísne genologické pravidlá, teda zásady žánrovej a druhovej určenosti, determinácie jednotlivých kategórií (napr. rigorózne členenie na divadelné druhy: divadlo poézie,

a zverejnená. Vít’azný text je publikovaný v časopise Svět a divadlo. Podrobnosti o sút'aži možno nájst' na internetovej stránke www.aurapont.cz.

10 Je anonymnou sút'ažou o najlepší slovenský dramatický text roka s ciel’om podporit’ rozvoj domácej tvorby a prepojit' ju s profesionálnym divadlom. Tejto sút’aže sa môže zúčastnit' slovenský autor s pôvodnou hrou, ktorá — podobne ako v prípade Ceny Alfréda Radoka — nebola ešte uvedená a zverejnená. Ocenené texty sú knižne publikované a inscenované v niektorom z profesionálnych slovenských divadiel. Podrobnosti o sút'aži možno nájst' na internetovej stránke www.theatre.sk.

11 Pozri bližšie http://www.divadlodisk.sk/index.php?td=disk alebo M. Breţák, M. Fehér, Divadelný súbor Trnava DISK 50. Publikácia kjubileu, Trnava 2005.

12 Pozri bližšie štúdie viacerých teatrológov venujúcich sa problematike alternatívneho, štúdiového, študentského, nezávislého a pod. divadla na Slovensku, ako napr. K. Horák, Konštanty a premeny divadla alternatívneho typu na Slovensku, [v:] Metamorfózy alternatívneho divadla, eds. M. Pukan, E. Kušnírová, P. Himič, Levoča 2009, s. 10-45, ako aj idem, Alternativne divadlo na Slovensku po roku 1989 II, [v:] Kontexty alternativneho divadla IV, eds. K. Horák, M. Pukan, E. Kušnírová, Prešov 2011, s. 8-40, alebo M. Mistrík, Alternatívne divadlo v súčasnej optike, [v:] Kontexty alternatívneho divadla I, eds. J. Gbúr, K. Horák, Prešov 2003, s. 36-40, alebo A. Jawlowska, Więcej niż teatr, Warszawa 1987, s. 5-36, alebo W. Dudzik, O teatrze alternatywnym, „Konteksty: Polska Sztuka Ludowa. Antropologia Kultury, Etnografia, Sztuka” 49, 1995, č. 2 [229]. 
malé javiskové formy, činohra, opera a i.), po historicko-spoločenskom medzníku v roku 1989 viacero produkcií — trebárs performančného charakteru — v rozličných typologických variantoch (performance, body art, site specific, happeningové akcie, postdramatické tendencie, dokumentárne divadlo a pod.) - narušilo dlhoročný stereotyp a vynútilo si na kultúrnom a umeleckom poli ich akceptovanie.

Možno to ilustrovat' aj na takom divadelnom festivale, ktorý už viac ako polstoročie kontinuálne zastrešuje kultúrne i popkultúrne aktivity a tvorbu vysokoškolákov na Slovensku s estetickým valérom, akým je Akademický Prešov (AP) ${ }^{13} \mathrm{~V}$ naznačených intenciách by sme sa mohli opriet' o všeobecnú charakteristiku pojmu performancia, ktorú Patrice Pavis, odvolávajúc sa na Andreau Nouryehovú a jej pät' performačných foriem, charakterizuje v Divadelnom slovniku nasledovne: „Body art (Telo ako umenie), ked’ sa telo perfomera používa na to, aby ho [...] ukázalo alebo overilo jeho imidž. ${ }^{14 “}$ Takou bola aj performancia realizovaná na 45. ročníku AP Telo ako objekt (2011). Performer si vbodol do hrude niekol'ko malých šípov so zástavkami a postupne ich vrhal pred seba a od jednej méty $\mathrm{k}$ druhej prechádzal priestorom. Taký typ performačnej produkcie by viac ako pred štvt'storočím - a to nielen $v$ kontexte tohto festivalu - nebol prakticky vôbec možný.

Inú štýlovú a typologickú tonalitu priniesla performancia Materstvo ako „autobiografická prezentácia, $\mathrm{v}$ ktorej umelec rozpráva reálne udalosti zo svojho života“. ${ }^{15}$ Tri členky Študentského divadla Filozofickej fakulty Prešovskej univerzity (ŠD FF PU) počas štúdia $v$ jednom akademickom roku otehotneli a priniesli na svet potomkov. ${ }^{16}$ Táto téma nebola aktérkami interpretovaná ako reprezentácia roly, ale mala charakter ostenzie a ponúkla bezprostrednú reálnu skúsenost', čím sa usilovala aj o konceptualizáciu divadelnej formy, tendujúc rovnako ku konceptuálnemu divadlu. Avšak

13 Vznikol v roku 1966 a od 3. ročníka je kontinuálne až dodnes organizovaný v Prešove ako Sút'až umeleckej tvorivosti vysokoškolákov Slovenska. Aj vd'aka prepojeniu na umeleckú činnost' Študentského divadla Filozofickej fakulty Prešovskej univerzity, ktorý inicioval jeho vznik, organizátori koncepčne preferujú na danom fóre, samozrejme, okrem domácich produkcií, rovnako aj viacero typov alternatívnej divadelnej kultúry, predovšetkým pol'skej a českej proveniencie, čo je rovnako potvrdením dôležitých a zároveň i živých relácií slovenského alternatívneho divadla s pol'skou alternatívnou divadelnou kultúrou. Z pol'ských súborov, ktoré sa za ostatné desat'ročie zúčastnili na tomto fóre možno napríklad spomenút: Teatr im. Wandy Siemaszkowej z Rzeszowa (Szajnov Déballage - Rozbal'ovanie), Teatr Cogitatur z Katowic (Izdebského Aztec Hotel), Cieszyńskie Studio Teatralne z Cieszyna (Słupczyńského Droga Žywiecka, Kaukazkij Privet), Teatr Krzyk z Maszewa (Kościółkove Głosy), Teatr Realistyczny z Skierniewic (Paluchovského Tra-ta-ta...), Scena Plastyczna z Lublina (Vilgoć Leszka Mądzika), Teatr Porywacze Ciał z Poznane (OUN Katarzyny Pawłowskej i Macieja Adamczyka), Teatr Nowy z Warszawy (Pasożyty Tomasza Gawrona), Teatr KTO z Krakowa (Quixotage, Ślepcy, Chór Sierot), Teatr Ósmego Dnia z Poznane (Archa) a mnohé d’alšie.

14 P. Pavis, Divadelný slovnik, Bratislava 2004, s. 302.

15 Ibidem.

16 Išlo o Dianu Laciakovú, Zuzanu Henčekovú a Zuzanu Dancákovú. Pozri bližšie D. Laciaková, Performance Materstvo, [v:] Kontexty alternatívneho divadla IV, s. 120-140. 
umelecký svojbytný postup genézy divadelného diela, pri ktorom na jeho začiatku nestojí hotový scenár, iba niekol'ko téz (zväčša ani graficky nezaznamenaných), odkazuje aj na divadlo improvizácie, tak často vysokoškolským súborom preferované. ${ }^{17}$

Narátorky neprinášaju len svoj pohl’ad na fabulu, ony ju „žijú“, je im vlastná, inak formulované - fabula produkuje prítomnost'. Možno spolu s Lehmannom dokonca uvažovat' tiež o „posteepickom divadle. ${ }^{18 ، ~ A v s ̌ a k ~ c ̌ i ́ m ~ v a ̈ c ̌ s ̌ i ́ m ~ m n o z ̌-~}$ stvom formálnych prostriedkov a tematických línií dielo disponuje, tým sa zvyšuje pravdepodobnost' ich prelínania sa, preskupovania a prerastania jedného do druhého. Okrem toho úsilie o všeobecne popisné pomenovania „síce predstaví nové diela, ale sústred'uje sa skôr na ich inventarizáciu a 'upratanie' než na pochopenie ich estetickej logiky. ${ }^{19 ،} \mathrm{~V}$ širších kontextových reláciách aktérky prezentovali sociálnu situáciu performeriek — poslucháčok vysokej školy (štúdium, rodina, diet'a, existenčné problémy a i.), pričom ich narácia do istej miery mala charakter spontánnych, jednorazových privátnych vyznaní. ${ }^{20}$ Pretože, ako tvrdí Hans-Thies Lehmann,

namiesto negatívneho vzt’ahu k predmetnosti zdôrazňuje sa bezprostredne vnímaná konkrétnost'. [...] Ide tu totiž o exponovanie divadla pre seba samého ako umenia v priestore, čase s l’udskými telami a vôbec všetkými prostriedkami, ktoré zahŕňa Gesamtkunstwerk, ktoré sa stávajú autonómnymi objektmi estetickej skúsenosti. ${ }^{21}$

Zvolenými scénickými prostriedkami, nehierarchicky usporiadaným textom, simultánnos'ou umeleckej fikcie dotváranej efektom scudzenia prostredníctvom kombinácie auditívnych a vizuálnych médiii ${ }^{22}$ a „životnej“ ontológie ostentatívne prenikajúcej a zasahujúcej do štruktúry diela vytvorili komornú, vysoko zážitkovú performanciu budovanú tak na autenticite prebiehajúceho okamihu narácie, ako aj na časovej univerzálnosti príbehu mladých matiek pri štarte do života.

Podobne aj divadelné formy typu site specific v minulosti, predovšetkým počnúc pät'desiatymi rokmi až do začiatku devät'desiatych rokov minulého storočia boli tak v oblasti profesionálneho, ako aj amatérskeho divadla na Slovensku (v Československu) takmer nemyslitel'né. Ak sa aj objavili, tak len sporadicky $\mathrm{v}$ rámci tzv. malých javiskových foriem. Po páde režimu, nivelizácii obmedzení a vyhlásení slobody tlače a vol’nosti slova sa otvorila cesta na progresívne ume-

${ }_{17}$ M. Pukan, Alternatívnost' ako jeden z možných ,, inscenačných “ prístupov v divadelnej tvorbe a praxi, [v:] Kontexty alternatívneho divadla III, eds. J. Gbúr, K. Horák, M. Pukan, Prešov 2008, s. 110 .

18 Podla H.T. Lehmann, Postdramatické divadlo, Bratislava 2007, s. 110.

19 M. Pšenička, Nejen k postdramatickému konceptu Hanse-Thiese Lehmanna, [v:] Divadelní revue, roč. 21,2010 , č. 1 , s. 39 .

20 Jedna z nich dokonca hrala s dojčat'om na hrudi.

${ }^{21}$ H.T. Lehmann, op. cit., s. 110.

22 Tie mali charakter autonómneho hráča prezentujúceho inú, simultánne existujúcu tvár sprítomnenej skutočnosti. V štruktúre diela sa využívali notebook, zosilňovač, dataprojektor, čítačka. $\mathrm{Z}$ dataprojektora sa na plátne objavili napríklad základné informácie protagonistiek traktovaného príbehu súvisiace s vekom, manželstvom, trvalým bydliskom a podobne. 
lecké artikulovanie rovnako aj duchovných princípov prostredníctvom tém, ktoré sa primárne viažu na osobitý, povedzme sakrálny priestor. V týchto intenciách sa umelecké vedenie festivalu orientovalo na témy úzko späté s východoslovenským regiónom prostredníctvom workshopov. Tak vznikla napríklad divadelná dielňa rekonštruujúca brutálne zavraždenie troch katolíckych kňazov v Košiciach: mad'arského Pongráca, chorvátskeho Križina, pol'ského Grodzieckého v období protihabsburských povstaní v roku 1619 nazvaná Apokryfy troch košických mučeníkov (2005) v réžii Karola Horáka. Takmer identickú genézu majú Prešovské jatky alebo Prešovský krvavý súd (2015), kde jeho tvorcovia tematizovali tragickú situáciu krutého súdu nad luteránskymi veriacimi v Prešove z roku 1687 a ich následnú popravu. Prezentácia sa odohrala $\mathrm{v}$ prešovskom sakrálnom priestore Evanjelického chrámu sv. Trojice, ktoré so študentmi v rámci workshopových podujatí AP naštudoval režisér a estetik Michal Babiak. V tejto súvislosti možno spomenút' aj životný príbeh Zdenky Schellingovej, rehol'nej sestry, ktorá zomrela $\mathrm{v}$ trnavskej nemocnici po nekompromisnej perzekúcii predošlého politického systému v ilavskom väzení (2003). ${ }^{23}$ Za zmienku stojí aj prezentácia workshopu Muž zlatého srdca (2015) v réžii Júlie Rázusovej tematizujúca t’aživé a zložité životné osudy gréckokatolíckeho biskupa Pavla Petra Gojdiča v pätdesiatych rokoch minulého storočia realizovaná v prešovskej gréckokatolíckej Katedrále sv. Jána Krstitel'a. Príbeh bol prerozprávaný fragmentárnymi reminiscenciami kňaza Mariana Potaša (Peter Lejko, herec DJZ), do ktorého vstupovali herci ŠD FF PU a kreovali pohybové obrazy mučeníkovho vzletu i pádu (poukázali na zverstvá bývalého režimu i t’ažobu, ktorú intelektuálna vlna v tomto období v Československu zakúšala). Jednotlivé sekvencie dotvárala sakrálna hudba a spolu s pestrou paletou výrazových prostriedkov (napr. videoprojekcia s fotografiami Pavla Petra Gojdiča), „živelným“ a fyzickým herectvom s prvkami pohybovej choreografie a improvizácie, $s$ dramaticky účinným prerušovaním prejavov protagonistov dupaním, kašlaním, zvukmi prepisovačiek, kombináciou skandovania s meditatívnymi textami, využitím historických faktov konfrontovaných s lyrickým, neraz modlitebným textom potvrdili intenzívny divadelný zážitok, kontaktujúc sa s recipientom od úvodného vstupu do chrámu až po poslednú sekvenciu projektu. Podobnú genézu mala rovnako divadelná dielňa Orkucanský proces 1764 (2016) naštudovaná Michalom Babiakom spolu s interpretmi ŠD FF PU v prešovskej synagóge na základe dokumentu autorov Teodora Austrelitza a Petra Kónyu Kodeš z Orkucian, v ktorom rozpracovali historickú udalost' súdneho procesu so Židmi na základe falošného obvinenia $\mathrm{z}$ rituálnej vraždy. ${ }^{24}$ Minimálnymi výrazovými

23 Inscenácia mala premiéru v roku 2003 na Akademickom Prešove v krypte prešovského Františkánskeho kostola v réžii Juliany Sersenovej.

24 Spomínaný židovský proces mal vel'ké rozmery s dohrou na viedenskom dvore. Prebiehal v rokoch 1764-1765. Všetko sa začalo vraždou 5. júla 1764, ked’ bol zavraždený pätročný chlapec, syn sedliaka Jána Ballu, ktorý sa hral so svojimi vrstovníkmi a nevrátil sa na obed ani na večeru. Našli ho na rozhraní chotárov medzi Orkucanmi a Jakubovanmi v lokalite Červený chrasc. Pri pre- 
prostriedkami v intenciách divadla oznamu, deklamačným herectvom, rituálnym spevom a náznakovou scénografiou pripomínajúcou tzv. scénu chudobného divadla vytvorili inscenátori $\mathrm{v}$ primárne nemúzickom priestore synagógy sugestívny príbeh nepravdivej obžaloby z údajnej rituálnej vraždy a nenávisti či likvidácie komunity.

Odlišný typ divadelnej poetiky — $\mathrm{v}$ intenciách site specific — reprezentoval opät' v rámci hlavného programu spomínaného študentského festivalu workshopový projekt Iné spätné zrkadlo (2004), ktorý jeho tvorcovia nazvali v podtitule „vstupovanie do duše protagonistky“. Usilovali sa v ňom vyjadrit” vnútorný svet ženy odlišným spôsobom ako v prípade inscenácie Spätné zrkadlo, ktorá mala premiéru v Štátnom divadle Košice (ŠD, 2005) v réžii Michala Babiaka. Osobitost' projektu spočívala $\mathrm{v}$ tom, že sa jeho prezentácia odohrávala $\mathrm{v}$ nedivadelnom prostredí protiatómového krytu Študentského domova a jedálne Prešovskej univerzity v Prešove. Jeho architektúra (sedem miestností so spájajúcimi chodbami) modifikovala vlastný charakter diela: publikum (20-30 divákov) prechádzalo od vstupu cez chodby popred jednotlivé biotopy, v ktorých interpretky (spolu s d'alšími hercami a heračkami) stvárňovali fragment protagonistikinho príbehu. Vol'ba tohto priestoru nebola náhodná. Žena — gastarbeiterka sa vo svojom monológu zmieni o tom, že na farme, kde pracovala s d'alšími kolegyňami, bývali spolu v protiatómovom kryte, ktorý v období studenej vojny stavali na Západe ako reakciu na prípadný nukleárny útok z Východu. Zásadná odlišnost' workshopovej verzie od inscenácie monodrámy v košicom ŠD spočívala v zmene žánru: monodramatický textový part pre jednu herečku realizovali v jednotlivých kójach protiatómového krytu štyri interpretky ( $\mathrm{k}$ nim treba prirátat' ešte rad d'alších aktérov — tanečnice,

hliadke mŕtvoly sa začalo tvrdit’, že na jeho tele našli nápis „Jeden je Boh“. Chlapec, ktorý sa s ním hral, uviedol, že videl kráčat po ceste dvoch Židov. Všetky úkony okolo mítvoly chlapca sa diali podl'a pokynov sudcu Pavla Zamboryho. Padlo obvinenie na Židov s tým, že je to rituálna vražda. Udalost' sa udiala pred turičnými sviatkami a to bol vraj dôvod vraždy, lebo boli smädní po krest'anskej krvi. Práve v tom čase Židia mali svoje zhromaždenie v Mošurove a tam ich pozatýkali na základe svedectva desat'ročného chlapca, syna Žida Jakuba Davidoviča z Mošurova, ktorý vraj počul rozhovor otca s mošurovským učitel'om Moše Josefovičom: „Postaraj sa, aby si vykonal to, na čom sme sa dohodli.“ Ďalším svedkom bola dojka v dome Ondreja Semsyho, pokrstená Židovka, ktorá počula takýto rozhovor: „Mali sme to diet’a predsa len skôr hodit’ do vody.“ Tretím svedkom bol jeden z obvinených Židov Samuel Šepsa z Mošurova, ktorý tvrdil, „že vraždu spáchal s mošurovským učitel'om Moše Josefovičom." Na základe výpovedí svedkov bola 14. júla 1764 vypracovaná obžaloba. Obžalovaní ostali traja Moše Josefovič, Josef Lefkovič a Samuel Šepsa. Z nich Moše Josefovič z Mošurova mučenie pri vyšetrovaní neprežil. Proces bol ukážkou falošnej obžaloby z rituálnej vraždy a nenávisti a likvidácie komunity, ktorá prekážala patričným zámerom. Za oslobodenie sa rozprúdila vel'ká mašinéria a proces sa potom nežiaduco predlžoval až jedenást' mesiacov. Pomoc a podporu v tomto procese poskytla Židovská náboženská obec, ktorá sa odvolávala až k cisárovnej Márii Terézii a tá sa obávala škandálu. Na jej pokyn bol proces zastavený a obvinení oslobodení, ale martýrom ostal práve Moše Josefovič, ktorý nevydržal vyšetrovanie. Proces bol zastavený až v apríli 1765. Židovská náboženská obec potom uctievala martýra v tomto procese na širokom okolí, ktorý vošiel do povedomia l’udí ako „Kodeš z Orkucan“. Pozri bližšie https://korzar.sme.sk/c/4569343/ orkucansky-zidovsky-proces.html\#ixzz4tW8pzLHr. 
chór, spevákov, „inštalátorov“, narátorov, demonštrátorov a pod.), ktorí v mozaike výjavov predstavovali ženu — či jej príbeh — z rozličných optík (vrátane polemických vo vztahu k prototextu alebo ironizujúcich niektoré činnosti hrdinky). Dôležitú úlohu v tejto kompozícii zohrala postava Sprievodcu — ženinho manžela. Ten privítal $\mathrm{v}$ chodbe pred krytom divákov, upozornil na seba hrou na bongo, predstavil ženu, voviedol ju i divákov do hracieho priestoru a prechádzal od jedného mikropriestoru symbolizujúceho celu $\mathrm{k}$ d’alšiemu, až publikum nakoniec vyviedol z krytu spät' do všedného života (nemožno sa ubránit' paralele tejto postavy s mýtickým Cháronom a ríšou Hádes). Publikum tak malo možnost' recipovat' nielen horizontálny príbeh tejto ženy, ale vo vertikálnej rovine (cez duchovný rozmer) aj jej zákutia — akúsi trinástu komnatu.

Pocit slobody vo vzt’ahu k nepredvídatel’nej komunikačnej situácii súčasného divadla môže $\mathrm{v}$ akomkol'vek spoločenskom systéme vyvolat' $\mathrm{v}$ jedincovi pragmatické dôsledky. Preto trebárs inscenácia Horákovej Džury realizovaná prešovským ŠD FF PU a označená prinajmenšom slovenskou kritickou obcou za kultovú, bola na prelome rokov 1969-1970 zásadne kritizovaná, ba upodozrievaná pre symboliku jamy, priepasti, džury ${ }^{25} \mathrm{z}$ hanenia vtedajšej predstavy, ako by mala vyzerat' súdobá súčasnost' a radená medzi ideologicky neprijatel'né divadelné diela. V prítomnosti — v jej remakových verziách — sa núkajú nečakané alúzie na dieru ako symbol dnešnej vyprázdnenej konzumnej spoločnosti, ktorá sa pozvol'na dostáva či skôr už dostala do hodnotového závozu.

Jednou z línií činnosti vysokoškolského súboru — ako sme naznačili - je rovnako remaková podoba emblémových inscenácií slovenského alternatívneho divadla (spomeňme rozličné verzie remakov Horákových hier, predovšetkým Džury, 1969-1971; Živého nábytku, 1975; Tip-top biotopu, 1976). Na pozadí eufórie zo slobody nepôsobia ani po rokoch ako archiválny, prachom zapadnutý dokument, skôr naopak, mnohé tematické línie tvoriace bazálny sujetový raster spomínaných hier vykazujú v súčasnosti vysoký stupeň spoločenskej aktuálnosti. Odkazuje to na skutočnost', že v predošlom spoločenskom systéme bola nepriatel'nou akákol'vek — aj skrytá či latentná univerzalita výpovede, ktorá mohla byt' chápaná prinajmenšom ambivalentne, čo z pohl’adu dnešného percipienta môže byt' neraz považované za nepochopitel'né, dokonca až za absurdné.

Narušenie dovtedajších stereotypov a prísneho ideologického direktizmu sa prejavilo jednak v už spomínanej žánrovej pestrosti divadelných diel a jednak v odmietnutí zaužívaného modelu oceňovania účastníkov AP v rámci jednotlivých kategórií: bolo tak aj v prípade udel'ovania 1.-3. miesta s odôvodnením, že športový výkon nie je oblast’ou kultúry a že sa, povedzme, akýkol'vek umelecký prejav a s ním spojená estetická kvalita len vel'mi t’ažko taxatívne určuje. ${ }^{26}$ Tvorca divadelných inscenácií v spomínanom type umeleckej kreativity amatérov -

${ }^{25}$ Ide o šarišský dialektický výraz označujúci jamu, otvor, dieru.

${ }^{26}$ Kvôli úplnosti treba podotknút', že v rámci kategórie študentské divadlá organizátori vyhlasujú namiesto poradia laureátov festivalu. 
vysokoškolákov je v súčasnosti už v pravom slova zmysle slobodný. Atrofovala železná ruka nekompromisne bdejúca nad tvorbou scenárov či dramatických textov, ktoré museli prejst' schval'ovacím pokračovaním ideologických komisií a sút’ažné divadelné programy sa vymanili z tortúry riadiacich štruktúr na vysokých školách alebo univerzitách.

S činnost'ou a tvorbou študentského divadla (no nielen s ním) súvisí aj d'alšia relevantná skutočnost': akoby sa už z kultúrnej pamäte takmer naplno vytratila doba sklonku šest'desiatych rokov 20. storočia, kedy sa v pol'skom kultúrnom prostredí formovali divadelné fóra napríklad typu Medzinárodného festivalu otvoreného divadla vo Vroclavi (Międzynarodowy Festiwal Teatru Otwartego we Wrocławiu), teda podujatia, ktoré významným spôsobom otvorilo - metonymicky povedané - „východnému divadelnému svetu“ obzor „celosvetového sveta“. Dokumentuje to aj Martin Porubjak vo svojej štúdii o jeho piatom ročníku s citátom z Litwincovho manifestu v záhlaví:

Byt' otvorený znamená byt' zodpovedný za všetko, čo je l'udské. A ked’že l'udská existencia má spoločenský rozmer, otvorené umenie sa zaujíma o osud človeka zasadeného $\mathrm{v}$ jeho spoločenstve triednom, národnom, skupinovom. Je umením politickým, pretože nazerá na jednotlivca z perspektívy jeho závislosti od spoločenských podmienok, vzájomných vplyvov, všetko, čo ohraničuje i otvára, čo zväzuje i oslobodzuje, ničí i chráni. Je citlivé, musí byt’ teda kritické. ${ }^{27}$

Zodpovednost' umelca nielen za stav umenia, ale stav sveta, aktívny vzt'ah ku skutočnosti, „potreba oponentúry tvorcu voči ,závislosti‘, ,vplyvom‘, ,ohraničeniam‘, ,zväzovaniu', potreba kritickosti $[\ldots]^{28 ،}$ Všetky tieto tézy vyznievali v sedemdesiatych rokoch 20 . storočia na pozadí dobovej, socialisticko-realistickej koncepcie umenia na Slovensku, presnejšie v Československu, ako ideologicky neprijatel'né. Martin Porubjak preferuje spoločensky apelatívne divadlo oproti „,nudnému estetskému“, povedzme „happeningové divadlo“ (Teatr 77 Łódź), ktoré nechce diváka „poučit"“, „pobavit"“, „vychovat"“, ale ho

chápe ako partnera vo vzt’ahu [...], je to spôsob inscenovania, ktorý diváka [...] nemôže nechat' chladným, l'ahostajným, ktorý ho môže bud' pohoršit', alebo vyprovokovat' k prehodnoteniu určitých stanovísk. Je to divadlo [...], ktoré aktivizuje [...], v skutku otvorené divadlo — otvorené voči divákovi, ochotné dávat' i prijímat'. ${ }^{29}$

Inscenácie svetových a európskych divadelných súborov napríklad Bread and Puppet, Living Theater, Odin Teatret, Laboratorium a celá plejáda pol’ských študentských divadiel vytvárali teda ilúziu o slobodnom umelcovi, slobodnom umení a kultúre, ktoré napriek ideologickým obmedzeniam spejú k svojej vít’aznej fáze: ked' kultúra a v jej rámci aj popkultúra bude môct' byt' samým sebou, bez akýchkol'vek riadiacich reštrikcií. Boli to nádeje podporené reprezentatívnymi dielami so svojbytnou poetikou a axiológiou $\mathrm{v}$ intenciách presvedčivého výpovedného

27 M. Porubjak, Prečo otvorené divadlo?, „Slovenské divadlo“ 24, 1976, č. 3, s. 402.

${ }^{28}$ K. Horák, Konštanty a premeny divadla alternativneho typu na Slovensku, [v:] K. Horák, Metamorfózy alternativneho divadla, s. 37.

29 M. Porubjak, op. cit., s. 410. 
sémantického gesta typu Grotowského chudobného divadla, divadelných komún predovšetkým americkej proveniencie, pozoruhodnej divadelnej kultúry pochádzajúcej z africkej či ázijskej zóny. Treba zdôraznit', že sedemdesiate a osemdesiate roky minulého storočia - ako sme spomenuli - neboli príliš priaznivo naklonené týmto inscenačným prejavom a s nimi bezprostredne súvisiaceho typu slobody, hoci každá zo stredoeurópskych krajín prinášala svoje nezamenitel'né špecifiká. Najkonzistentnejšou sa nám predsa len javí pol'ská divadelná kultúra, ktorá aj $\mathrm{v}$ predošlom politickom systéme rozvíjala poetiku študentského divadla ako oponenta voči dominantnej oficiálnej „straníckej kultúre“ či umeniu, pričom nielen $\mathrm{v}$ ideovej, ale aj v esteticko-etickej rovine popierala jej konformné, konvenčné, metódou socialistického realizmu poznačené modely tvorby. Tento festival pozvol'na atrofoval, a hoci neskôr v pol'skom kultúrnom prostredí boli podmienky pre kreovanie d'alších festivalov mapujúcich alternatívne divadelné prístupy domácich a zahraničných tvorcov, nazdávame sa, že takéto esteticky progresívne vzopätie zo sklonku šest'desiatych rokov minulého storočia možno dnes len t'ažko zaevidovat'.

Po tzv. spoločensko-historickom a politickom prevrate by sme mohli a nielen $\mathrm{v}$ hypotetickej rovine - uvažovat' o novej situácii tvorcov otvoreného divadla. Zdá sa však, že hoci sa kvantitatívne posilnilo pole jeho osobností či telies, taký typ divadelných zoskupení, súborov či komún, o akých sme v našej štúdii na sklonku šest'desiatych rokov predošlého storočia uvažovali, v súčasnosti, žial', nejestvuje. Je to dané osobitými vývinovými okolnost'ami dnešnej kultúry, neopomínajúc ani popkultúrne kontexty, čo možno postrehnút' predovšetkým na pozadí špecifickej situácie niekdajších krajín východného bloku, v ktorých kultúra s inými jej sférami t’ahá za kratší koniec.

V slovenskej dráme a divadle neexistuje prevládajúci trend, o ktorý by sa autori opierali. Na dôvody, prečo nie je rozpoznatel'ný určujúci trend v slovenskej dráme, respektíve, škola, poukazuje aj J. Šimko, ktorý tvrdí, že divadlá predovšetkým nepracujú systematicky s domácimi autormi, dokonca o texty domácich autorov nestoja. Druhým problémom je dostupnost' svetovej klasiky a súčasnej drámy na javiskách. Na Slovensku pocitujeme absenciu silnej tradície v inscenovaní realistických hier západoeurópskej proveniencie a hier z obdobia moderny, od ktorých sa súčasná svetová dráma odvodzuje. Tretím problémom je dostupnost' dramatickej literatúry v slovenskom jazyku. Z mnohých titulov chýbajú elementárne preklady, o komentovaných akademických vydaniach klasikov nehovoriac. ${ }^{30}$ Podl'a všetkého by sme sa mali v súčasnom prechodnom období - pochopitel'ne vo sfére nonkonformného, experimentálneho, „nového“ umenia a osobitej kultúrnej situácie — inšpirovat' možno liminalitou, ktorú by sme v širšom slova zmysle mohli

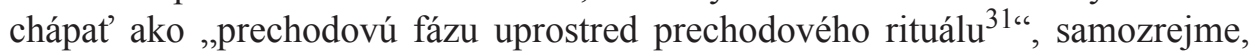

30 Podl’a J. Šimko, op. cit., s. 14.

31 A. Nünning a kol., Lexikon teorie literatury a kultury, Brno 2006, s. 447-448. 
v obraznom slova zmysle. Prechodové rituály chápeme ako ,zobrazovanie procesov zmeny a sociálnej premeny, ako nielen priestorové prekračovanie hraníc. ${ }^{32 ،}$ To je do určitej miery intencia a možno aj pracovné označenie spoločensko-kultúrnych procesov v súčasnosti, ktoré napriek mnohým optimistickým prognózam o prirodzenom inkorporovaní slobody ako bytostného a prirodzeného fundamentu tvorcov a divákov, sú predsa len v stave liminálnom.

\title{
Between liminality and freedom as the manifestation of the discourse of the (pop)(sub)culture in the contemporary Slovak alternative Theater
}

\author{
Summary
}

The release in postmodern and postdramatic society after 1989 was reflected — was also reflected in many changes in theatre and drama. A lot of new authors and shows have appeared. The original drama, however, is very slow at the stage of major theatres. Whereas, in the seventeenth and eighteenth century normalization seasons, the determinations of individual categories prevailed in the culture and art (and not only the theatrical) strict genological rules. Nevertheless, this long-standing stereotype has been eroded by a number of dramatic productions with various typological features (performance, body art, site-specific art, happening event, post-dramatic tendencies, documentary theatre, etc.), thus cultural and artistic acceptance has been enforced. The paper illustrates this state with several productions of the Student of the Faculty of Arts of Prešov University (Other Back Mirror 2004; Apocrypha of the Three Košice Martyrs, 2005; Body as an Object; Maternity, both in 2011; Slaugterhouse or Prešov Bloody Court, The Man of the Golden Heart, both in 2015; Orcucal Process 1764, 2016, Jura Remakes, Live Furniture, Tip-top Biotope, 2006-2014), presented at the Academic Prešov Theatrical Festival, which has been covering aesthetically valuable cultural activities and production of college students in Slovakia for over half-century.

32 Ibidem, s. 448. Podl'a van Genepovej koncepcie by sme si mohli osvojit', so zretel'om na kulturologicko-antropologické hl'adisko, tri fázy liminality: „oddelenie od pôvodného miesta alebo stavu — prechod stavom, ktorý je na hrane medzi oboma svetmi — a začlenenie sa do nového spôsobu bytia“. Ibidem. 